\title{
Revisi dan Uji Pembelajaran Desain Instruksional Diklat Jarak Jauh Online Penelitian Tindakan Kelas di Balai Dikat Keagamaan Jakarta
}

\author{
Asip Suryadi \\ Balai Diklat Keagamaan Jakarta \\ asipsuryadi@kemenag.go.id, asip_sayurradi@yahoo.co.id
}

\begin{abstract}
This study aims to develop instructional system of Classroom Action Research Online Distance Training at BDK Jakarta. This development research uses the Borg, Borg and Gall models. This research is a part of the research and development series, namely the product revision step and the use test. The revised results a simpler curriculum structure and learning activities. Furthermore, the instructional design was tested to 80 participants and data showed that training participants were no longer trapped at the beginning of the program and could continue to follow the program easily, resulting in an increase in the percentage of graduation from before the revision was only $24 \%$ after the revision to $71.42 \%$. However, instructional improvements have not been able to improve retention. This study recommends continuing instructional designs development so that the instructional design can improve both the percentage of graduation and retention.
\end{abstract}

Keywords: instructional design, Online Distance Training, Classroom action research, research and development.

\begin{abstract}
Penelitian ini bertujuan untuk mengembangkan desain instruksional Diklat Jarak Jauh Online Penelitian Tindakan Kelas di BDK Jakarta. Penelitian pengembangan ini menggunakan model Borg, Borg dan Gall. Penelitian in hanya menyajikan sebagain dari rangkaian penelitian dan pengembangan saja yaitu pada langkah revisi produk dan uiji coba pemakaian. Hasil revisi menghasilkan struktur kurikulum dan kegiatan belajar yang lebih sederhana. Selanjutnya data hasil uji coba terhadap 80 peserta Diklat menunjukkan bahwa peserta diklat tidak lagi terjebak di awal program dan dapat melanjutkan untuk mengikuti program dengan mudah sehingga terjadi kenaikan persentasi kelulusan dari sebelum revisi hanya $24 \%$ di setelah revisi menjadi $71.42 \%$. Namun demikian perbaikin instruksional belum dapat meningkatkan penguasaan materi substansi (kognitif). Penelitian ini merekomendasikan untuk terus mengembangkan desain istruksional sehingga selain dapat meningkatkan hasil belajar psikomotorik dan persentasi kelulusan juga dapat meningkatkan retensi.
\end{abstract}

Kata Kunci: desain instrksional, Diklat Jarak Jauh Online, PTK, revisi, riserch and development, ,

\section{PENDAHULUAN}

Sebagai sebuah inovasi baru DJJ Online di BDK Jakarta masih memiliki banyak kelemahan. Salah stau kelemahan utama adalah masih rendahnya tingkat kelulusan. Masalah ini terjadi di seluruh jenis DJJ Online di BDK Jakarta. Termasuk pada DJJ Online Penelitian Tindakan Kelas
(PTK). Berdasarkan hasil evaluasi DJJ Online tahun 2014 pada DJJ Online Penelitian Tindakan Kelas (PTK) tingkat kelulusan baru mencapai ratarata $32 \%$.

Ditinjau dari teori sistem, tingkat kelulusan sebagai output ditentukan oleh komponen dan sub komponen 
yang terlibat dalam system online learning. Kelemahan pada salah satu atau beberapa komponen/sub komponen dapat menyebabkan rendahnya tingkat kelulusan. Semakin baik mutu komponen maka berpeluang akan menghasilkan jumlah dan mutu output yang semakin baik dan sebaliknya.

Moore (Moore \& Anderson, 2003, p. 58), Andersson dan Gerison (Anderson, 2008) menyebutkan tiga komponen online learning yaitu peserta didik dan sumber belajar. Menurut Khan (Khan, 2005, p. 14), ada delapan komponen pada sistem e-learning yaitu pedagogical (pedagogi), technological (teknologi), interface design (tampilan), evaluation (evaluasi), management (pengelolaan), resources support (sember daya), ethical (etika), dan institutional (kelembagaan). Sedangkan Anderson dan Gerison menambahkan 3 bentuk interaksi lain yaitu gugu-guru, gurusumber dan sumber-sumber.

Komponen-komponen tersebut berinteraksi antara satu dengan lainnya. Michael Moore menyebutkan tiga bentuk interaksi yaitu peserta didik-peserta didik, peserta didikguru/tutor dan peserta didik-sumber belajar. Dalam proses interaksi tersebut fungsi dari sistem keseluruhan tidak dapat dilihat dari fungsi masingmasing komponen melainkan harus dilihat dari keseluruhannya. Namun demikian kelemahan fungsi yang dialami oleh salah satu komponen akan berpengaruh terhadap interkasi keseluruhan. Oleh karena itu setiap komponen harus bermutu sehingga dapat berfungsi dengan baik. Semakin bermutu komponen-komponenya maka semakin tinggi jaminan bahwa interaksi antara setiap komponen dapat terjadi dengan lancar. Selanjutnya, semakin baik interaksi antara komponen maka akan semakin baik mutu proses dan hasil belajaran.

Teori sistem instruksional tersebut dapat dijadikan kerangka teoretis pengembangan sistem instruksional pada DJJ Online Penelitian Tindakan Kelas. Berdasarkan teori tersebut apabila hasil Diklat online belum optimal maka salah satu faktor penyebabnya dapat ditelusuri dalam mutu komponen dan mutu interaksi pembelajaran.

Peneliti telah melakukan penelitian dan engembangan (R\&D) dalam mengembangkan DJJ Online Penelitian Tndakan Kelas sejak tahun 2014. Penelitian sudah pada tahap uji coba produk. Uji coba dilakukan dengan cara menyajikan pebelajaran dalam skala terbatas terhadap 40 peserta Diklat. Hasil uji coba menunjukkan bahwa peserta Diklat mengalami kesulitan mengikutinya. Indikaot utamnya adalah kelulusan hanya sampai 32\%.

Hasil telaah menunjukkan bahwa banyak peserta yang tidak dapat mengikuti pembelajaran di kegiatan belajar pertama. Dari 40 peserta yang terdaftar di Kegiatan Belajar 1 (KB 1), hanya 26 peserta yang dapat 
melanjutkan ke Kegiatan Belajar 2 (KB 2). Selanjutnya semakin berkurang hingga haya tersisa 13 peserta di akhir program.

Hasil refleksi dengan tutor dan admin, ditambah dengan hasil survey melalui SMS terhadap beberapa peserta yang tidak melanjutkan ke KB 2, ditemukan penyebab utamanya yaitu tugas KB 1 terlalu sulit dan membutuhkan waktu yang panjang untuk mengerjakanya. Diprediksi peserta mengalami kesulitan, kepanikan, kekagetan dan ketakuatn di awal sehingga berkesan bahwa DJJ Online PTK sulit sehingga menurunkan motivasi untuk melanjutkan. Akhirnya mereka memutuskan untuk berhenti.

$$
\text { Hasil evaluasi tersebut }
$$
ditindaklanjuti dengan melakukan langkah R\&D selanjutnya yaitu revisi prosuk. Dalam langkah tersebut dilakukan tinjauan ulang struktur kurikulum, kegiatan belajar dan media dan sumber belajar, mengidentifikasi kelemahan dan melakukan revisi. Revisi dilakukan dengan tujuan agar sistem instruksional menjadi lebih ramah peserta sehingga pembelajaran dapat diikuti dengan mudah, cepat dan hasilnya baik. Pada kondisi tersbut pada akhirnya dapat meningkatkan persentasi kelulusan.

\section{METODOLOGI}

Dalam penelitian ini digunakan metode penelitian pengembangan (research and development/R\&D) Borg, Borg dan Gall (Gall, Gall, \& Borg,
2003). Model R\&D yang digunakan berfokus kepada perancangan dan evaluasi produk/program tertentu dengan tujuan untuk memperoleh gambaran tentang proses pengembangan serta mempelajari kondisi yang mendukung bagi implementasi program tersebut (Richey, Klein, \& Nerson, 2004). Dalam $\mathrm{R}$ \& $\mathrm{D}$ tersebut digunakan langkah Borg dan Gall yang disederhanakan seperti pada skema berikut (Sugiono, 2009).

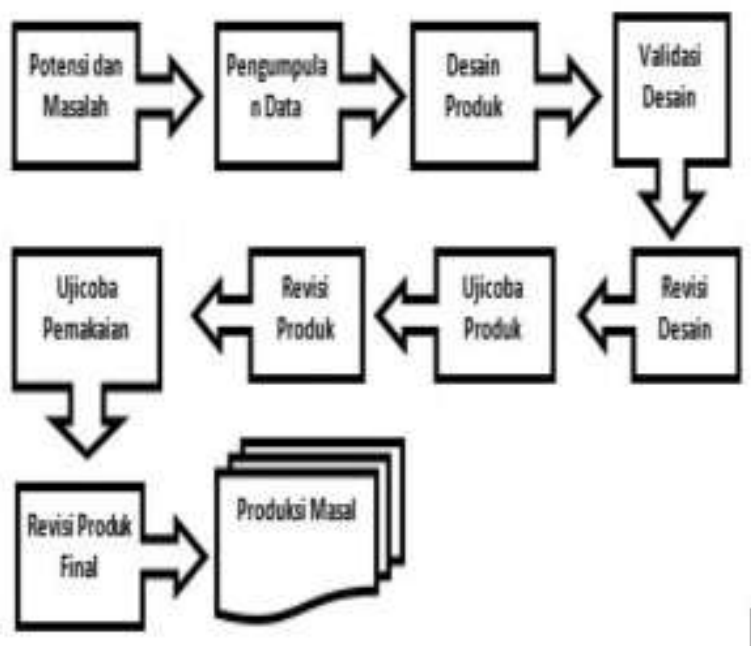

Gambar 1 Skema Model Penelitian Borg, Borg dan Gall

Penelitian ini merupakan salah satu bagian dari rangkaian dari penelitian pengembangan desin instruksional Diklat Jarak Jauh Online Penelitian Tindakan Kelas di Balai DIklat Keagamaan Jakarta. Fokus penelitian hanya pada langkah revisi produk dan uji coba pemakaian.

Data penelitian dikumpulkan melalui survey, wawancara dan focus group discussion (FGD). Sumber data utama yang akan digunakan adalah dokumen instruksional, LMS DJJ 
Online PTK, tim pengembang dan tutor. Selain itu data tambahan diambil dari Grup Facebook PTK Angkatan 2015. Data berbentuk kualitatif diolah menggunakan analisis induktif, sedangkan data kuantitatif diolah menggunakan statistic uji perbedaan (uji t).

\section{HASIL REVISI DAN UJI COBA \\ Revisi Desain Instruksional}

Pada langkah revisi produk telah dilakukan telaah terhadap data yang diunduh dari rekam jejak belajar peserta, hasil FGD dengan tim pengembangan, perbincangan di media social dan wawancara. Hasil telaah digunakan untuk melakuka revisi insruksional. Berikut ini perubahan beberapa komponen pada desain isntruksional sebelum dan seudah direvisi.

\section{Tujuan Instruksional}

Perubahan pertama yang berdampak terhadap kompnen lainnya adalah perubahan pada tujuan instruksional. Perubahan tersebut dapat dilihat pada tabel berikut.

\section{Tabel 1 Perubahan Tujuan Instruksional}

\begin{tabular}{|c|c|}
\hline SEBELUM & SESUDAH \\
\hline $\begin{array}{l}\text { Setelah selesai } \\
\text { mengikuti diklat ini } \\
\text { peserta diklat } \\
\text { diharapkan dapat } \\
\text { melakukan } \\
\text { Penelitian Tindakan } \\
\text { Kelas sebagai salah } \\
\text { satu upaya } \\
\text { peningkatan kualitas } \\
\text { pembelajaran dan } \\
\text { menyusun } \\
\text { laporannya sebagai } \\
\text { karya tulis ilmiah }\end{array}$ & $\begin{array}{l}\text { Setelah selesai } \\
\text { mengikuti diklat } \\
\text { peserta diharapkan } \\
\text { memahami konsep } \\
\text { dan prosedur } \\
\text { melaksanakan } \\
\text { Penelitian Tindakan } \\
\text { Kelas serta dapat } \\
\text { menyusun rencana } \\
\text { pelaksanaannya } \\
\text { dalam bentuk } \\
\text { proposal. }\end{array}$ \\
\hline
\end{tabular}

(KTI)

\section{Kompetensi Dasar}

Tabel 2 Perubahan Kompetensi Dasar

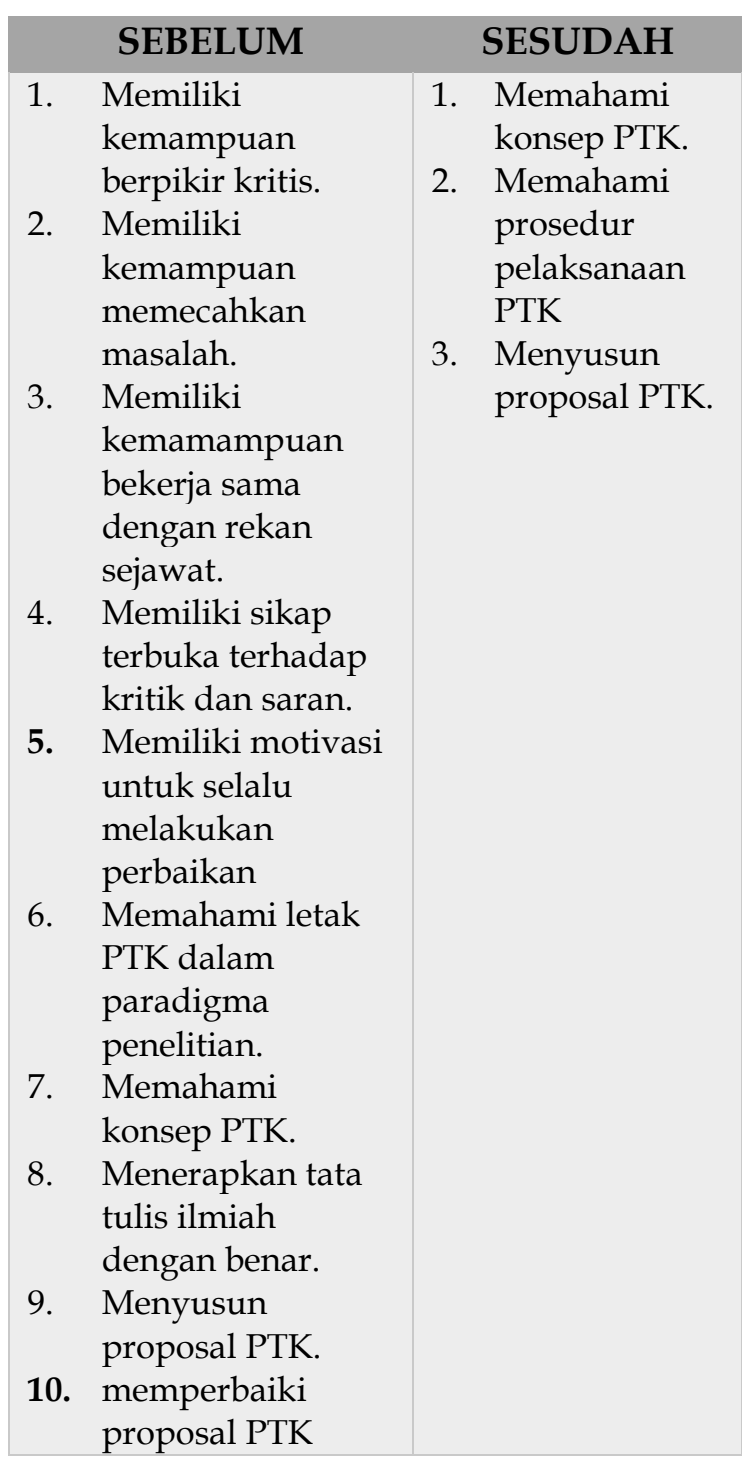

\section{Struktur Kurikulum}

Tabel 3 Struktur Kurikulum Sebeluam Revisi

\begin{tabular}{|l|c|}
\hline \multicolumn{1}{|c|}{ MATERI AJAR } & JAM \\
DIKLAT
\end{tabular}




\section{Wawasan}

Jurnal Balai Diklat Keagamaan Jakarta

PISSN 2548-9232; eISSN .....

Volume 1 Nomor 1 Tahun 2020:49-59

\begin{tabular}{|l|c|}
\hline Seminar Proposal PTK & 10 \\
\hline Evaluasi Program & 5 \\
\hline Jumlah jam pelajaran & 80 \\
\hline
\end{tabular}

Tabel 4 Struktur Kurikulum Stelah Revisi

\begin{tabular}{|l|c|}
\hline \multicolumn{1}{|c|}{ MATERI AJAR } & JAM DIKLAT \\
\hline Orientasi Program & 5 \\
\hline Konsep PTK & 20 \\
\hline Komponen dan & 15 \\
sistematika Proposal PTK & \\
\hline Teknik Menyusun & 45 \\
Proposal PTK & \\
\hline Seminar Proposal PTK & 10 \\
\hline Evaluasi Program & 5 \\
\hline Jumlah jam pelajaran & 100 \\
\hline
\end{tabular}

\section{Kegiatan Belajar}

Tabel 5 Struktur Kegiatan Belajar Sebeum Revisi

\begin{tabular}{l|c|}
\multicolumn{1}{|c|}{ MODUL } & WAKTU \\
\hline Orientasi Program & 1 minggu \\
\hline $\begin{array}{l}\text { Kegiatan Belaajar 1: } \\
\text { Posisi PTK dalam } \\
\text { Paradigma penelitian }\end{array}$ & 2 minggu \\
\hline $\begin{array}{l}\text { Kegiatan Belajar 2: } \\
\text { Konsep PTK }\end{array}$ & 2 minggu \\
\hline $\begin{array}{l}\text { Kegiatan Belajar 3: Tata } \\
\text { Tulis Ilmiah dan Teknik } \\
\text { penyusunan proposal } \\
\text { PTK }\end{array}$ & 5 minggu \\
\hline $\begin{array}{l}\text { Kegiatan Belajar 4: } \\
\text { Seminar Proposal PTK }\end{array}$ & 1 minggu \\
\hline Evalusi program & 1 minggu \\
\hline Jumlah & 11 minggu \\
\hline
\end{tabular}

Tabel 6 Struktur Kegiatan Setelah Revisi

\begin{tabular}{|l|l|}
\multicolumn{1}{|c|}{ MODUL } & WAKTU \\
\hline Orientasi program & $1 \mathrm{minggu}$ \\
\hline Kegiatan Belajar 1: Konsep PTK & $1 \mathrm{minggu}$ \\
\hline $\begin{array}{l}\text { Kegaitan Belajar 2: Proposal } \\
\text { PTK }\end{array}$ & $1 \mathrm{minggu}$ \\
\hline $\begin{array}{l}\text { Kegiatan Belajar 3: Teknil } \\
\text { Penyusunan Proposal Bab 1. }\end{array}$ & $1 \mathrm{minggu}$ \\
\hline
\end{tabular}

\begin{tabular}{l|c}
$\begin{array}{l}\text { Kegiatan Belajar 4: Teknik } \\
\text { Penyusunan Proposal Bab 2. }\end{array}$ & 2 minggu \\
\hline $\begin{array}{l}\text { Kegiatan Belajar 5: Teknik } \\
\text { Penyusunan Proposal Bab 3. }\end{array}$ & 6 minggu \\
\hline $\begin{array}{l}\text { Kegiatan Belajar 6: Seminar } \\
\text { Proposal PTK }\end{array}$ & 1 minggu \\
\hline $\begin{array}{l}\text { Evaluasi program } \\
\text { Jumlah }\end{array}$ & 1 minggu \\
\hline
\end{tabular}

\section{Retensi}

Tabel 7 Perbandingan Hasil Pretes

\begin{tabular}{|l|c|c|}
\hline & \multicolumn{2}{c}{ PRETES } \\
\hline Rerata & SEBELUM & SESUDAH \\
\hline Standar Deviasi & 13.91 & 50.22 \\
\hline Skor tertinggi & 74.07 & 9.23 \\
\hline Skor terendah & 31.85 & 68.33 \\
\hline
\end{tabular}

Tabel 8 Perbandingan Hasil Postes

\begin{tabular}{|l|c|c|}
\hline & \multicolumn{2}{c}{ POSTES } \\
\hline Rerata & 90.72 & 88.54 \\
\hline Standar Deviasi & 7.50 & 11.91 \\
\hline Skor tertinggi & 100 & 98.33 \\
\hline Skor terendah & 78.98 & 60.17 \\
\hline
\end{tabular}

\section{Tugas Ahir}

Tabel 9 Perbandingan Skor Tugas Akhir

\begin{tabular}{|l|c|c|}
\hline & SEBELUM & SESUDAH \\
\hline Rerata & 89.75 & 91.19 \\
\hline Standar Deviasi & 5.25 & 5.00 \\
\hline Skor tertinggi & 98.00 & 98.00 \\
\hline SKor terendah & 82.00 & 81.00 \\
\hline
\end{tabular}

\section{Kelulusan}

Tabel 10 Perbandingan Persentasi Lulusan

\begin{tabular}{|l|c|c|}
\hline \multicolumn{1}{|c|}{ KEGIATAN } & \multicolumn{2}{c|}{ JUMLAH } \\
\hline & SEBELUM & SESUDAH \\
\hline Orientasi program & 33 & 80 \\
\hline Kegiatan Belajar 1 & 13 & 76 \\
\hline Kegiatan Belajar 2 & 13 & 72 \\
\hline
\end{tabular}




\begin{tabular}{|l|c|c|}
\hline Kegiatan Belajar 3 & 8 & 64 \\
\hline Kegiatan Belajar 4 & 8 & 61 \\
\hline Kegiatan Belajar 5 & 8 & 60 \\
\hline Kegiatan Belajar 6 & 8 & 59 \\
\hline Evaluasi program & 8 & 57 \\
\hline Tes sumatif & 8 & 57 \\
\hline Persen Kelulusan & 24.24 & 71.42 \\
\hline
\end{tabular}

\section{Pembahasan}

Data pada tabel menujukkan perubahan-perubahan baik pada desain instruksional maupun dampaknya terhadap hasil pembelajaran. Yang pertama telah terjadi perubahan tujuan instruksional. Kalimat tujuan pembelajaran pada desain instruksional DJJ Online PTK tahun 2014 menargetkan peserta untuk dapat melakukan PTK. Setelah dikaji ulang target pembelajaran tersebut tidak tercapai melakui pembelajaran karena sesi pembelajaran tidak sampai kepada simulasi melakukan PTK. Oleh karena itu target pembelajaran diperbaiki hanya sampai memahami konsep dan dapat menyusun proposal PTK.

Kedua kompetensi dasar disederhanakan. Penyederhanaan dilakukan karena beberapa competesnsi dasar tidak substansial dan hanya merupakan turunan dari yang lainnya. Penyederhanaan kompetensi dasar tidak terlalu berpengaruh terhadap perubahan keseluruhan karena tidak mengubah tinfkat dan jumlah kompetensi.

Ketiga pada struktur kurikulum. Dua tabel menunjukkan terjadinya perubahan signifikan pada struktur kurikulum. Perubahan terjadi pada materi dan kedua pada ekivalensi bobot jam pelajarannya. Perubahan tersebut dilakukan atas beberapa alasan. Pertama, kegiatan belajar pada DJJ Online PTK tahun 2014 terlalu kompleks, terutama pada materi pertama, yaitu posisi PTK dalam penelitian. Materi ini tingkatannya terlalu tinggi sehingga susah dipahami bagi sebagian guru. Materi ini terletak di kegiatan pertama dan hal ini yang menyebabkan peserta tak mampu melanjutkan ke kegiatan berikutnya. Secara psikologis ketika orang menemukan sesuatu dan merasa kesulitan maka wajar kalau ada yang tidak memaksakan diri untuk maju ke langkah berikutnya. Bagaian awal saja sudah sulit, apalagi bagian berikutnya.

Keempat pada kegiatan belajar. Berdasarkan materi dan kegiatan di kegiatan belajar awal disederhanakan sehingga tidak menjegal peserta di awal, dan tidak mematahkan semangat. Selain itu materi dirinci sehingga memberikan dampak lebih mudah dipelajari. Teknik penyusunan proposal yang tadinya disatukan berikutnya dipisah menjadi dua bagian yaitu sistematika dan komponen proposal, baru kemudian teknik penyusunan proposal. Pada prakteknya teknik penyusunan proposal dibagi tiga kegiatan yaitu teknik menyusun proposal bab 1 , tekni menyusun proposal abab 2 dan teknik penyusunan proposal bab 3. 
Kelima, penambahan ekivalensi jam pelajaran memiliki alasan kuat. Berdasatkan pelaksanaan DJJ Online PTK tahun 2014 banyak peserta yang tertinggal karena mereka merasa waktu tidak cukup. Peserta adalah guru yang setiap harinya memiiki tugas utama mengajar sehingga hanya punya sedikit waktu untuk mengerjakan hal lain. Penambahan $20 \mathrm{JP}$ memberkan peluang kepada peserta untuk meyelesaikan materi yang sama dalam waktu yang relatif senggang. Meskipun sebenarnya masalah terlambat adalah masalah kemampuan pengelolaan diri namun diharapkan penambahan jam tersebut dapt memberikan kelegaan.

Pada DJJ PTK tahun 2014 pembelajaran disajikan dalam enam modul belajar sedangkan pada DJJ Online 2015 disajikan dalam delapan modul dengan susunan dan alokasi waktu sebagai berikut. Tabel Modul DJJ Online PTK 2014

Berlatarbelakang banyaknya peserta yang gugur terutama di kegiatan belajar pertama maka modul belajar diperbaiki. Seperti telah dikemkakan bahwa pada pelaksanaan DJJ Online PTK tahun 2014 sekitar 50\% peserta gugur di Kegiatan Belajar 1 dengan materi "Posisi PTK dalam Paradigma Penelitian". Diprediksi beberapa penyebab fenomena tersebut. Pertama materi terlalu tinggi, kedua penempatan di awal kegiatan, ketiga, tugas-tugas pada kegiatan belajar tersebut terlalu berat dan keempat waktu yang disediakan tidak cukup untuk menyelesaikan tugas-tugas yang dimaksud.

Berdasarkan alasan tersebut materi "Posisi PTK dalam Paradigma Penelitian" direduksi kedalam konsep PTK. Artinya materi ini tidak menjadi focus utama melainkan hanya dijadikan pengetahuan penunjang untuk memahami Konsep PK.

Sebenarnya materi tersebut penting untuk dipahami oleh peserta karena berdasarkan pengalaman pelatihan PTK terutama pada Diklat Substantif, Banyak peserta yang sulit memahami Konsep PTK akibat kurang memahami paradigmanya. Banyak peserta yang memahami PTK seperti penelitian positivistic terutama experiment. Akibatnya ketika peserta menyusun proposal, mereka masih berpikir dengan paradigma experimental. Cara berpikir ini yang menyebabkan peserta sulit menentukan kompone-komponen penelitian dalam PTK. Seharunya ketika mereka berbicara PTK maka peserta harus berpindah paradigm dari penelitian positivistik ke penelitian tindakan/reflektif.

Untuk menyederhanakan pada Desain Instruksional DJJ Online PTK 2015 modul menjadi lebih rinci sehingga bertambah dari semula 4 kegiatan belajar menjadi 6 kegiatan belajar. Pada modul kegiatan Belajar 1 materi dirinci menjadi dua bagian yaitu konsep penelitian tindakan dan konsep penelitian tindakan kelas. Pada Kegiatan belajar 2 materi dipecah 
menjadi dua bagian, pertama menenai proposal, komponen dan sistematika; kedua teknik penyusunan proposal. Pada materi latihan penyusunan proposal dibagi menjadi 3 bagian yaitu teknik penyusunan bab 1 , teknik penyusunan bab 2, dan teknik penyusunan bab 3 .

Dengan penyederhanaan dan perincian seperti itu, ditambah dengan penambahan waktu penyelesaian peserta merasa lebih nyaman. Dampak utama terlihat hanya sedikit peserta yang gugur di kegiatan belajar pertama dan terjadi peningkatan peserta yang menyelesaikan Diklat.

Keenam sistem penilaian tidak mengalami perubahan dalam DJJ Online PTK tahun 2015 hanya mengalami editing pada soal-soal dan penyesuaian topik diskusi dan instruksi tugas sebagai akibat dari perubahan strategi pembelajaran.

Penilaian menggunakan aspek belajar bloom yaitu sikap pengetahuan dan keterampilan. Konsep yang diterapkan adalah terdapat irisan (intersection) antara ketiga aspek sehingga penguasaan terhadap satu aspek akan berpengaruh terhadap penguasaan lainnya dengan dipengaruhi oleh banyak factor. Konsep tersebut digambarkan sebagai berikut.

Bobot ketiga aspek tersebut sebagai berikut.

Penguasaan substansi materi $\quad$ : $40 \%$ Produk : $30 \%$
Sikap : $30 \%$

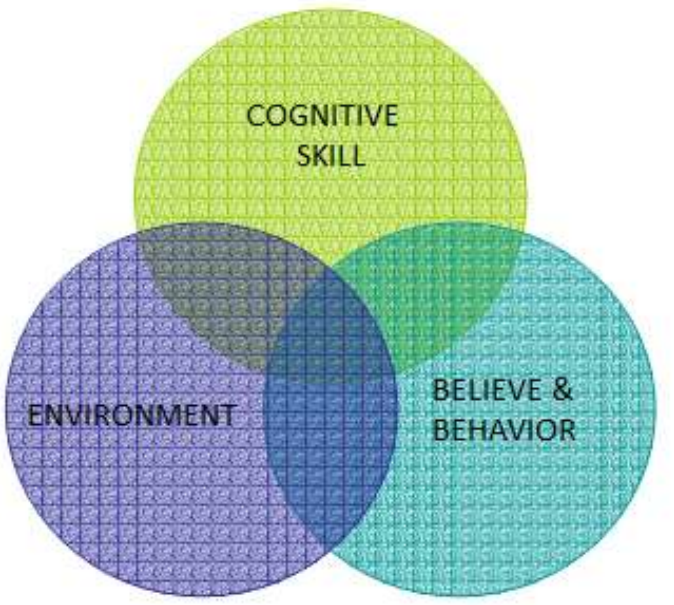

Gambar 2 Irisan aspek sikap, pengetahuan dan keterampilan

Ketujuah mengenai persentase lulusan. Data menunjukkan bahwa pada DJJ Online PTK 2014 jumlah peserta yang lulus hanya $24.24 \%$. Pada DJJ Online PTK 2015, jumlah peserta yang lulus 57 orang dari semula 80 orang. Ini berarti tingkat kelulusan mencapai $71.42 \%$. Fenomena ini menunjukkan indikasi bahwa perbaikan sistem instruksional berdampak teerhadap peningkatan persentase kelulusan.

Berikutnya diperoleh data menarik. Pada DJJ Online PTK 2014, $45.8 \%$ peserta tidak lulus pada kegiatan belajar pertama; sedangkan pada DJJ Online PTK 2015 hanya 4\%. Fenomena ini juga menujukkan indikasi bahwa penyederhanaan kegiatan pada kegiatan belajar pertama berdampak terhadap jumlah peserta yang gugur di awal Diklat.

Berdasarkan hasil penelitian yang dilakukan Pepina Mungania 
(Mungania, 2003) sukses e-learning ditentukan oleh tiga pilar yaitu person (cognitive skill), behavior (perilaku), dan environment (lingkungan). Ketiga pilar tersebut saling berarsiran antara satu dengan lainnya seperti dalam diagram berikut. Yang dimaksud dengan lingkungan oleh Mungania adalah framework yang diajukan oleh Badrul Khan yang meliputi 8 komponen instruksional. Daintaranya adalah komponen pedagogi yang didalamnya berhubungan dengan strategi pembelajaran.

Berdasarkan

kesimpulan Mungania tersebut tentu fenomena peningkatan persentase kelulusan pada DJJ Online PTK tahun 2015 tidak hanya disebabkan oleh komponen pedagogis melalui penyederhanaa modul dan perbaikan strategi pembelajaran, melainkan juga ditentukan oleh faktor pribadi dan keyakinan partisipan partisipan. Bisa saja dua factor teersebut yang lebih berpengaruh. Namun demikian belum dilakkan uji tingkat kontribusi faktor-faktor teersebut sehingga factor mana yang lebih berdampak.

Kedelapan mengenai penguasaan materi kognitif. Untuk menunjukkan peningkatan penguasaan peserta materi PTK maka yang harus dikaji adalah peningkatan atau selisih dari skor pretes ke skor postest. Pada DJJ Online PTK 2014 skor post tes adalah 90.72, sedangkan skor pretest 53.12. Data tersebut menujukkan selisih sebaasar 37.60. Pada DJJ Online PTK
2015 skor post tes adalah 88.54, sedangkan skor pretest 50.02. Data tersebut menujukkan selisih sebaasar 38.32. Angka-angka tersebut menunjukkan adanya petingkatan tipis sebesar 0.72. Sekilas saja peningkatan tersebut tidak signifikan. Tidak signifikannya data tersebut diperlihatkan oleh skor tertinggi dan skor terendah yang menunjukkan bahwa pada Pada DJJ Online PTK 2014 angkanya lebih tinggi. Bahkan pada Pada DJJ Online PTK 2014 ada peserta yang mencapai skor sempurna (100). Ini indikasi bahwa faktor individu (Kognitif skill dan believe-behavior) lebih berpengaruh.

Angka standar deviasi yang tinggi baik pada Pada DJJ Online PTK 2014 dan Pada DJJ Online PTK 2015, menunjukkan bahwa perolehan hasil belajar tidak merata. Ini merupakan indikasi bahwa strategi yang diterapkan belum membantu setiap peserta untuk menguasai skill yang diharapkan secara merata.

Berdasarkan uji perbedaan dua rata-rata pada taraf signifikan 5\% diperoleh $\mathrm{t}$ hitung sebesar -1.54 dan $\mathrm{t}$ tabel pada dk 80 adalah 1.66. Daerah penolakan pada taraf signifikan 0.05 untuk jumlah sampel 80 adalah $-1.66<t$ hitung $<$ 1.66. Angka tersebut menyatakan bahwa tidak terdapat perbedaan signifikan antara rata-rata skor uji kompetensi awal dengan uji kompetensi akhir. Berdasarkan uji perbandingan dua rata-rata pada taraf 
signifikan 0.05 dinyatakan bahwa perubahan tersebut tidak signifikan.

Kedua fakta di atas menunjukkan bahwa perbaikan sistem instruksional belum dapat meningkatkan rerata sor hasil belajar konsep secara signifikan. Strategi harus diperbaiki sehingga lebih memberikan fasilitasi kepada peserta yang secara individual memiliki kognitif skil, believe dan behavior yang relative rendah.

Kedelapan, tugas akhir yang dikumpulkan adalah proposal lengkap tiga bab dengan kelengkapannya. Proposal ini merupakan kompilasi dari kegiatan belajar latihan penyusunan proposal yang dalam DJJ Online PTK 2015 dirinci menjadi 3 Kegiatan belajar. Seperti halnya pada hasil pre-postest, secara kuantitatif angka-angka tidak menunjukkan perbedaan yang signifikan.

\section{KESIMPULAN DAN EKOMENDASI Kesimpulan}

Berdasarkan data dan hasill pembahasan dapat dirumuskan beberapa simpulan sebagai berikut.

1. Terjadi peningkatan persentase kelulusan dari $24.24 \%$ pada DJJ Online PTK 2014 menjadi 71.42\% DJJ Online PTK 2015. Peningkatan signifikan ini diakibatkan oleh perubahan sistem instruksional pada Kegiatan Belajar 1 yang tadinya terlalu kompleks menjadi lebih sederhana.

2. Terjadi peningkatan hasil belajar yang ditunjukkan oleh skor pre-pos tes dan skor tugas akhir, namun peningkatan tersebut tidak signifikan. Dapat disimpulkan bahwa perubahan system instruksional tidak menikkan tingkat pencapapain tujuan pembelajaran.

3. Perbaikan sistem instruksional tidak berdampak mencolok terhadap persepsi peserta mengenai tingkat keberfungsian system dan layanan tutor. Namun demikian kedua aspek tersebut mendapat penilaian sangat naik dari peserta.

\section{Rekomendasi}

1. DJJ Online di BDK Jakarta merupakan sebuah inovasi. Inovasi ini memiliki banyak kelebihan dan diprediksi akan menjadi model Diklat utama di masa yang kana dating. Di balik kelebihan tersebut banyak sekali kelemahan yang dialami. Salah satunya adalah masih rendahnya tingkat kelulusan peserta. Kelemahan ini tentu saja masih dapat ditingkatkan dengan terus menerus mengevaluasi dan memperbaikinya. Berdasarkan hasil kajian ini diajukan beberapa rekomendasi berikut.

1. Selalu melakukan evaluasi setiap selesai penyelenggaraan DJJ untuk mengidentifikasi ketercapaian tujuan instruksional dan keberfungsian sistem kemudian mengajukan rekomendasi untuk perbaikan pada setiap komponen. 
2. Setiap instansi kediklatan meningkatkan perhatian terhadap DJJ Online dengan cara membuat kebijakan lokal untuk mengembangkan manajemen pengelolaan DJJ.

3. Meningkatkan kompetensi pengelolaan DJJ Online baik bagi tutor maupun admin.

4. Berupaya melakukan pengadaan, pemeliharaan, pembaruan (updating) dan pengebangan media dan sarana DJJ Online secara berkelanjutan.

\section{DAFTAR PUSTAKA}

Anderson, T. (2008). The Theory and Practices of ONline Lerning Second Edition. Athabrasca: Athabrasca University Press.

Gall, D., Gall, M. J., \& Borg, W. (2003). Education Research an Introduction Sevent Edition. Boston: Longman Inc.
Khan, B. (2005). Managing E-Learning Strategies: Design, Delivery, Implementation and Evaluation. London: Information Scence Publishing.

Moore, M., \& Anderson, W. (2003). Handbook of Distance Education. London: Lawrence Erbaum Associatiates Publishing.

Mungania, P. (2003). The Seven ELearning Barriers Facing Employee. Retrieved Mei 5, 2016, from University of Luisville: http://www.academia.edu/842 0360

Richey, R. C., Klein, J. D., \& Nerson, W. A. (2004). Handbook of Research on Educational Communication and Technology. New Jersey: Lowrence Erbaum Associates.

Sugiono. (2009). Metode Penelitian Pendidikan Pendekatan Kuantitatif, Kualitatif, dan $R \in \mathcal{E} D$. Bandung: Alfabeta. 